\title{
EXPERIMENTAL INVESTIGATION OF CONCRETE BEAMS REINFORCED WITH BASALT FRP BARS
}

\author{
Gehan A. Hamdy ${ }^{1}$ and Dalia F. Arafa ${ }^{2}$ \\ ${ }^{1}$ Professor, Faculty of Engineering at Shoubra, Benha University, Cairo, Egypt \\ gehamdy1@gmail.com \\ ${ }^{2}$ Researcher, Reinforced Concrete Institute, Housing and Building National Research Center, \\ Dokki, Giza, Egypt \\ daliafarafa@yahoo.com
}

\begin{abstract}
Bars fabricated from basalt fiber-reinforced polymers (BFRP) are a new material used as an alternative to steel bars in reinforced concrete to overcome corrosion problems especially in harsh and aggressive environments. Basalt fibers also have high tensile strength and enhanced durability, in addition to moderate cost. This research investigates experimentally the flexural behavior of BFRP reinforced beams compared to steel RC beams. In the experimental program, six concrete beams reinforced by BFRP bars, BFRP bars and dispersed steel fibers and steel bars are tested in four-point bending until failure. The experimental results regarding failure load, failure mechanism and deflection of beams are discussed and are compared with published experimental results. Additionally, theoretical predictions for the moment carrying capacity and failure loads are computed using local and international codes, and were found to be consistent with the experimental results.
\end{abstract}

Keywords Beam, concrete, FRP reinforcement, BFRP bars, flexure, experimental

\section{Introduction}

Durability of structures is regarded an important aspect of design. Corrosion of steel reinforcement is considered a serious problem which shortens the service life of traditional reinforced concrete (RC) structures, especially those subjected to aggressive environment. Advanced materials such as fiber-reinforced polymer (FRP) have been used as reinforcement for concrete to avoid corrosion-caused deterioration, in addition to other desirable properties such as high specific strength and high specific stiffness [1]. The current design codes and guidelines allow the use of glass-, carbon- and aramid-FRP as the main reinforcement in concrete structures and provide design recommendations for using these bars. New fibers are continuously developed, such as basalt fibers possessing high tensile strength, corrosion resistance, good acid and alkali resistance, low moisture absorption, in addition to good thermal and electrical insulating properties and moderate cost [2-5]. Bars fabricated from basalt fiber-reinforced polymers (BFRP) were introduced as alternative to steel bars in reinforced concrete (RC) [6,7]. The tensile behavior of BFRP bars is characterized by linear elastic stress-strain relationship up to failure, which may cause concrete beams reinforced with BFRP bars to exhibit brittle failure without warning [7]. For this reason, design codes specify over-reinforced FRP design since the nonlinear behavior of concrete in the compression zone may give warning before failure. Being a relatively new material, studies on the short- and long-term performance of concrete beams reinforced by BFRP bars are limited. Additionally, the current FRP specifications and design guidelines do not include BFRP reinforced or strengthened elements. Experimental research investigated the flexural behavior of concrete beams reinforced by BFRP bars and compared it to 
beams reinforced with steel [8-15]. Increase in flexural capacity, greater deflections and wider cracks were reported for BFRP reinforced beams compared to steel reinforced beams, and it was recommended that serviceability limit states (deflection and width of cracks) should be the major factor in designing BFRP reinforced concrete beams [8-10]. Comparison of experimental results with predictions of FRP design codes and guidelines showed that the ultimate loads calculated according to ACI 440 and Eurocode 2 were underestimated [10, 11]. Beams with BFRP bars as flexural reinforcement as well as chopped basalt fibers were tested by High et al. [12] and showed increase of the modulus of rupture. Hybrid reinforcements of BFRP and steel was proposed by some researchers in order to meet the requirements of strength, deflection and minimum cracking at the same time [13, 14]. The aim of this research is to investigate the flexural behavior of beams reinforced by BFRP bars. An experimental program was conducted in which four BFRP RC beams and two steel RC beams were tested under four-point bending. Failure loads, failure mechanisms and deflections of the beams are examined and compared. The ultimate loads for the tested beams are also calculated using the American and Egyptian codes and compared with the experimentally determined values.

Table 1. Details of the tested Beam Specimens

\begin{tabular}{|c|c|c|c|c|c|}
\hline Beam No. & Beam ID & Reinforcement Type & Bottom Rft & Top Rft. & Stirrups \\
\hline 1 & BS1 & Steel hars & 3016 & \multirow{6}{*}{$\begin{array}{c}\text { Steel } \\
2 \emptyset 10\end{array}$} & \multirow{6}{*}{$\begin{array}{c}\text { Steel } \\
\text { 8mm@150 mm middle } \\
\text { third, 8mm@120 mm } \\
\text { sides of beam }\end{array}$} \\
\hline 2 & BS2 & Stere vals & 30 & & \\
\hline 3 & BB1 & \multirow{2}{*}{ Basalt bars } & \multirow{2}{*}{$2 \varnothing 15$} & & \\
\hline 4 & BB2 & & & & \\
\hline 5 & $\mathrm{BBF} 1$ & \multirow{2}{*}{$\begin{array}{l}\text { Basalt bars } \\
+ \text { Steel fibers }\end{array}$} & \multirow{2}{*}{$2 \varnothing 15$} & & \\
\hline 6 & BBF2 & & & & \\
\hline
\end{tabular}

\section{Experimental Program}

An experimental program was conducted where six beams were cast and tested in four point bending until failure; the beams details are given in Table 1. Two control beams S1 and S2 were reinforced by steel bars. Four beams had BFRP bars as bottom reinforcement, two of these beams BB1 and BB2 used normal strength concrete and in the other two BBF1 and BBF2, steel fibers were added to the concrete mix. The mix proportions for normal and steel fiber concrete are given in Table 2. All experimental work was carried out in the Reinforced Concrete Structures Research Institute Laboratory at the Housing and Building National Research Center in Giza, Egypt.

Table 2. Mix proportions for the concrete mixes

\begin{tabular}{|l|c|c|c|c|c|c|}
\hline $\begin{array}{l}\text { Type of } \\
\text { Mix }\end{array}$ & $\begin{array}{c}\text { Cement } \\
(\mathrm{kg})\end{array}$ & $\begin{array}{c}\text { Coarse } \\
\text { aggregate } \\
(\mathrm{kg})\end{array}$ & $\begin{array}{c}\text { Fine } \\
\text { aggregate } \\
(\mathrm{kg})\end{array}$ & $\begin{array}{c}\text { Water } \\
(\mathrm{L})\end{array}$ & $\begin{array}{c}\text { Additive } \\
(\mathrm{L})\end{array}$ & $\begin{array}{c}\text { Steel } \\
\text { fibers } \\
(\mathrm{kg})\end{array}$ \\
\hline $\begin{array}{l}\text { Normal } \\
\text { Concrete } \\
\text { Mix }\end{array}$ & 325 & 1102 & 735 & 172 & 7.5 & ----- \\
\hline $\begin{array}{l}\text { Steel } \\
\text { Fiber } \\
\text { Concrete } \\
\text { Mix }\end{array}$ & 325 & 1102 & 735 & 172 & 7.5 & 72 \\
\hline
\end{tabular}

\subsection{Material Properties}

Concrete: Concrete used for all beams had a characteristic compressive strength at 28 days of 38.25 MPa. The concrete with mix proportions given in Table 2 was prepared from ordinary Portland cement Type I according to ASTM C150 [17], natural sand and crushed natural dolomite aggregate with maximum nominal size of $10 \mathrm{~mm}$, additive Sikament 163 used to increase workability.

Steel reinforcement: Longitudinal reinforcement was steel of grade (B500DWR) [23] $f_{y}=600 \mathrm{MPa}$ (average of three tested samples) and $E_{\mathrm{s}}=200 \mathrm{GPa}$, diameter 
10 and $16 \mathrm{~mm}$ for top and bottom reinforcement, respectively. Stirrups were smooth bars $8 \mathrm{~mm}$ diameter, of mild steel grade (B240D-P) [23], $f_{y}=240$ $\mathrm{MPa}$ and $E_{\mathrm{S}}=200 \mathrm{GPa}$.

Basalt FRP bars: Basalt-fiber-reinforced polymer (BFRP) bars used as tension reinforcement have diameter $15 \mathrm{~mm}$, length $2000 \mathrm{~mm}$, sand-coated surface over helical wire wrapping, as shown in Fig.
2, to increase bond between the bars and concrete. Three bar specimens were tested in axial tension, the resulting mechanical properties were: ultimate tensile strength $f_{f u}=902.36 \mathrm{MPa}$, modulus of elasticity $E_{f}$ $=56.9 \mathrm{GPa}$, and maximum strain $=1.53 \%$.

Steel fibers: Steel fibers of diameter $0.50 \mathrm{~mm}$, length $30 \mathrm{~mm}$ and hooked ends were added to the concrete mix, and are shown in Fig. 2.
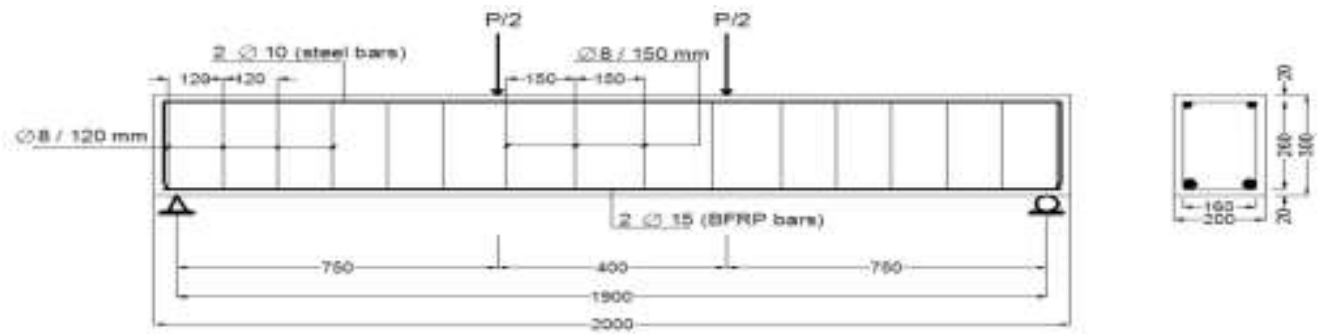

Fig. 1. Dimensions and Reinforcement Details of BFRP Bars reinforced Beams (all dimensions in mm)
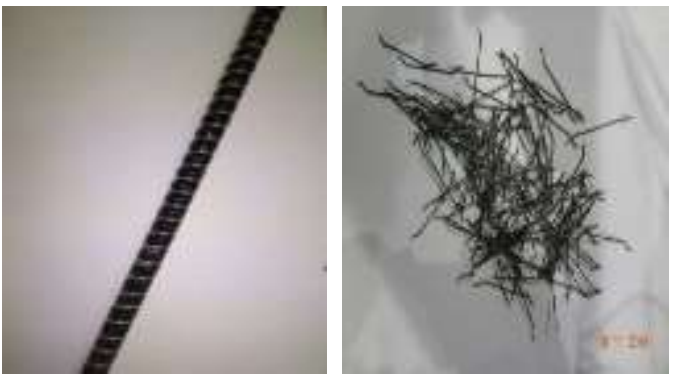

Fig. 2. BFRP bar and steel fibers used for Beam Reinforcement

\subsection{Beam specimens}

All the beams had cross-section of $200 \mathrm{~mm} \times 300$ $\mathrm{mm}$, total length of $2.0 \mathrm{~m}$ and span of $1.90 \mathrm{~m}$. The dimensions and reinforcement details of the tested beams are given in Table 1 and shown Fig. 1. Two control beams were reinforced with three steel bars $16 \mathrm{~mm}$ diameter as bottom reinforcement. Four beams had bottom reinforcement of two BFRP bars, and were designed in accordance with ACI 440 1R-15 [16] requirements as over-reinforced so as to fail by concrete crushing not by reinforcement rupture. In two of these beams, steel fibers were added to the concrete mix as $1 \%$ by volume. For all six beams, concrete cover was $20 \mathrm{~mm}$, two steel bars $10 \mathrm{~mm}$ diameter were used as compression reinforcement, and shear reinforcement consisted of mild steel bars $8 \mathrm{~mm}$ diameter spaced $120 \mathrm{~mm}$ near beam supports and $150 \mathrm{~mm}$ at middle third region. Normalstrength concrete with characteristic compressive strength at 28 days of $38.25 \mathrm{MPa}$ was used; the concrete mix proportions are given in Table 2. Concrete mixes were batched in laboratory, mixed in a tilting drum mixer, placed in molds and compacted using tamping rods, as shown in Fig.3. The cast specimens were allowed to set for 24 hours in the mold, then were demolded and placed in water-filled tank for 28 days before testing.

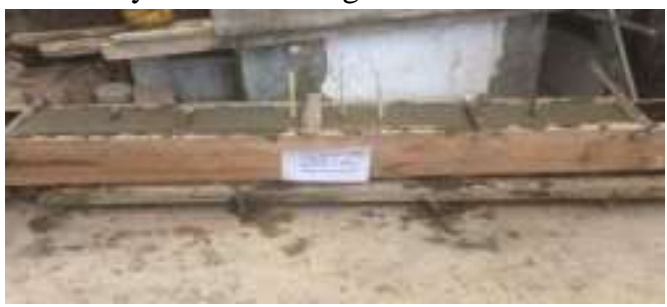

Fig. 3. Casting of Beams 


\subsection{Tests for mechanical properties of concrete and BFRP Bars}

For each concrete mix, three standard concrete cubes $(150 \times 150 \times 150 \mathrm{~mm})$ and three cylinders (150 $\mathrm{mm}$ diameter and $300 \mathrm{~mm}$ height) were cast and cured in the laboratory. After 28 days, cube compressive strength test and split-cylinder testing were made, as shown in Fig.4. The average compressive strength of concrete and fibrous concrete was $38.25 \mathrm{MPa}$ and $43.80 \mathrm{MPa}$, respectively. The average tensile strength values for cylinders of concrete and concrete with steel fibers were $3 \mathrm{MPa}$ and $3.70 \mathrm{MPa}$, respectively. Three coupons of basalt bars were tested in axial tension according to ASTM D7205 [15] in a universal testing machine. In order to avoid premature failure of BFRP bar in the anchorage zone, a special mounting system was designed and used where a steel pipe $200 \mathrm{~mm}$ long having outer diameter of $55 \mathrm{~mm}$ was attached at each end using epoxy resin and hardener. One strain gauge was glued on the mid length of the tested bar to measure the strains in bar during testing. BFRP bar configuration and testing are shown in Fig.5. The resulting stress-strain relation is plotted in Fig.6. The average tensile strength, modulus of elasticity and maximum tensile strain of BFRP bars are $f_{\mathrm{fu}}=902.36 \mathrm{MPa}, E_{f}=$ $56.9 \mathrm{GPa}$, and $\varepsilon_{\mathrm{fu}}=0.0153$, respectively.
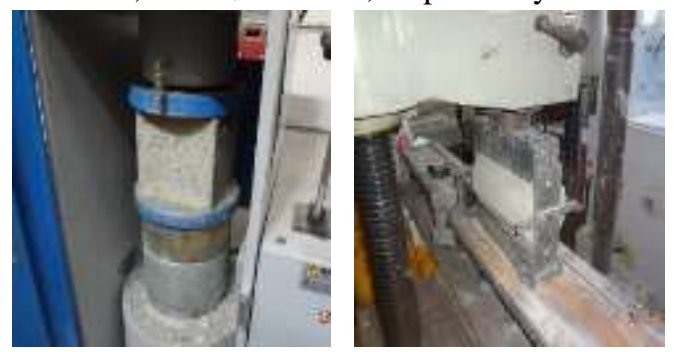

Fig. 4. Compressive Strength Testing of Concrete cube and indirect-Tension Test for Concrete Cylinder
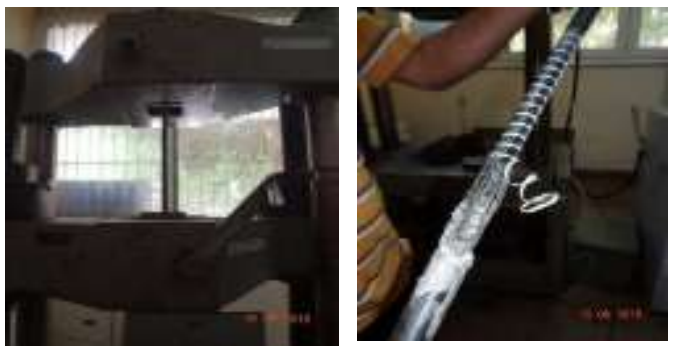

Fig. 5. Uniaxial Tension Test for BFRP Bar

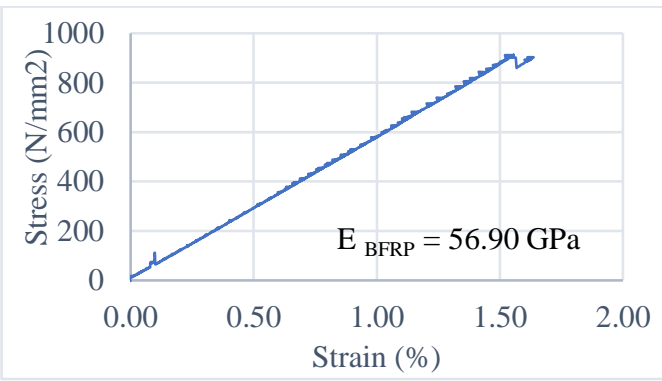

Fig. 6. Experimental results for Stress-Strain of BFRP Rebar

\subsection{Test Set-up and Test Procedure for Bending Test of Beams}

All beams were tested in four-point bending until failure in a universal testing machine with $1000 \mathrm{kN}$ capacity. The experimental test set up for beam specimen is shown in Fig.7. The specimens were arranged with simply supported conditions with an effective span of $1900 \mathrm{~mm}$. The beams were loaded by hydraulic actuator and steel spreader beam was used to distribute the load into two equal loads on the tested specimen. The two equal loads were $400 \mathrm{~mm}$ apart and $750 \mathrm{~mm}$ from the supports to ensure flexural failure. The load was increased at a uniform rate until failure. Deflection of the beam was measured using a dial gauge of least count $0.01 \mathrm{~mm}$ at center of the specimen. Three Linear Variable Differential Transformers (LVDTs) were used to measure deflection, one at the center of the beam and under the loads applied. Data acquisition system was connected to record load and deflection. 


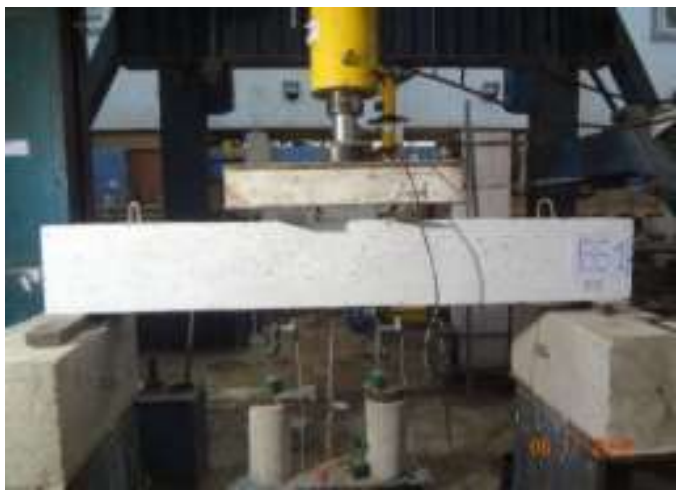

Fig. 7. Test setup for four-point bending Test of Beam

3.

\section{Experimental Results}

\subsection{Load-deflection Behavior and Failure Loads}

The relationship between the applied load and mid-span deflection for all beams is shown in Fig.8. Fig.9 shows the relationship between load and measured tensile strains in reinforcement bars throughout the test. The failure loads for the experimentally tested beams are listed in Table 3.

\subsection{Failure Modes}

Fig.10 shows the crack patterns at failure for three concrete beams: BS1, BB2 and BBF1. In specimen BS1 reinforced with steel bars, the first crack appeared at the constant moment region, then several cracks started to develop from the beam bottom surface extending vertically upwards. As the load increased, cracks started to propagate further from the constantmoment region towards the supports. Cracks outside this region were affected by combined flexure and shear stresses causing diagonally inclined cracks near the supports. Specimen BS1, designed as under-reinforced section, behaved in a ductile manner and the mode of failure was a flexure failure. In specimen BB2 reinforced by BFRP bars, the first crack appeared at a load equal to $27 \mathrm{kN}$ then cracks fewer than those of specimen BS1 developed at the tension side of the beam at constant moment region. By increasing the load, diagonal cracks spread near the supports and started to get wider and upwards towards the compression fiber of beam ending with crushing of concrete; this failure mode complied with its design as overreinforced section. In specimen BBF1 reinforced by BFRP bars and dispersed steel fibers, the first crack appeared at a load equal to $50 \mathrm{kN}$, then several cracks developed at the tension fiber of the beam at constant moment region. By increasing the load, diagonal cracks spread near the supports and started to get wider and spread upwards towards the compression fiber of beam ending with crushing of concrete. The specimen showed more ductility compared to specimen BB2, with more cracks before failure. Wider crack widths with less crack propagation are

observed in specimens reinforced with basalt bars than steel reinforced concrete beams.

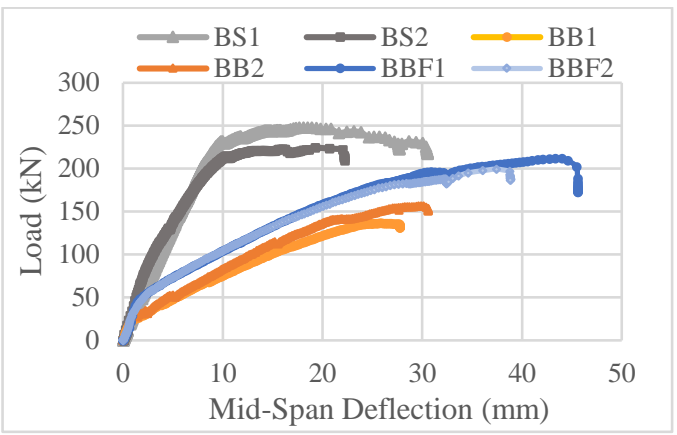

Fig. 8. Load-Deflection for Beams at Room Temperature

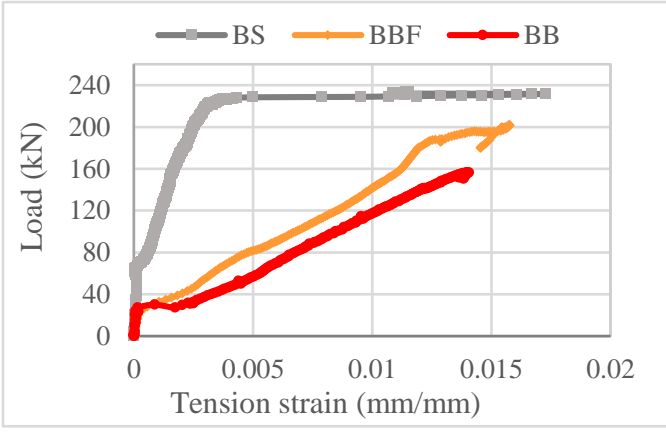

Fig. 9. Load-Strain for Beams BS, BB and BBF 


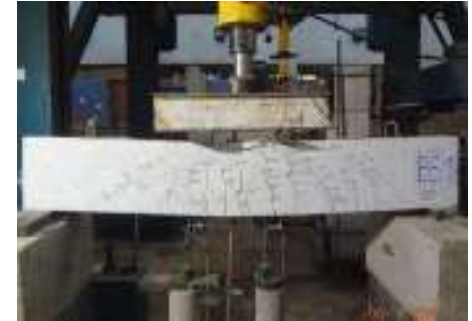

(a)

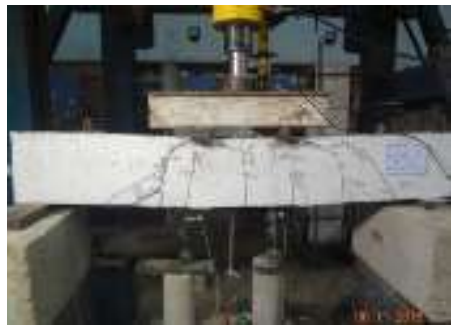

(b)

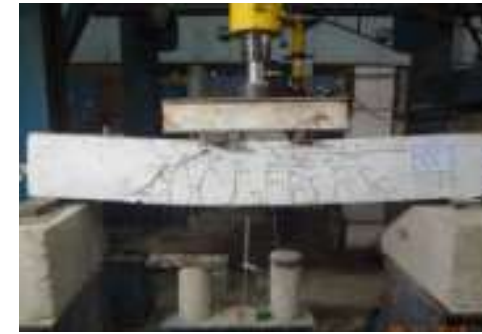

(c)

Fig. 10. Crack Pattern and Failure Mode of Beams (a) BS, (b) BB, (c) BBF

Table 3. Ultimate Loads and Mid-Span Deflections for tested Beams

\begin{tabular}{|c|c|c|c|c|c|c|c|}
\hline $\begin{array}{c}\text { Beam } \\
\text { Notations }\end{array}$ & Beam ID & $\begin{array}{l}\mathbf{P u} \\
(\mathrm{kN})\end{array}$ & $\underset{(\mathrm{mm})}{\Delta}$ & $\begin{array}{c}\text { Avg. } \mathbf{A} \\
(\mathrm{mm})\end{array}$ & $\underset{(\mathrm{kN})}{\operatorname{Avg.~Pu}}$ & $\mathbf{P u} / \mathbf{P} \mathbf{u}_{\text {steelRC }}$ & $\begin{array}{c}\text { Temperature } \\
\text { Exposure }\end{array}$ \\
\hline 1 & BS1 & 247.70 & 18.50 & \multirow{2}{*}{18.87} & \multirow{2}{*}{236.20} & \multirow{2}{*}{1.00} & \multirow{6}{*}{ Room temp. } \\
\hline 2 & BS2 & 224.30 & 19.26 & & & & \\
\hline 3 & BB1 & 136.50 & 25.91 & \multirow{2}{*}{28.00} & \multirow{2}{*}{146.50} & \multirow{2}{*}{0.62} & \\
\hline 4 & BB2 & 156.50 & 30.14 & & & & \\
\hline 5 & BBF1 & 211.60 & 43.97 & \multirow{2}{*}{40.69} & \multirow{2}{*}{205.50} & \multirow{2}{*}{0.87} & \\
\hline 6 & BBF2 & 199.40 & 37.41 & & & & \\
\hline
\end{tabular}

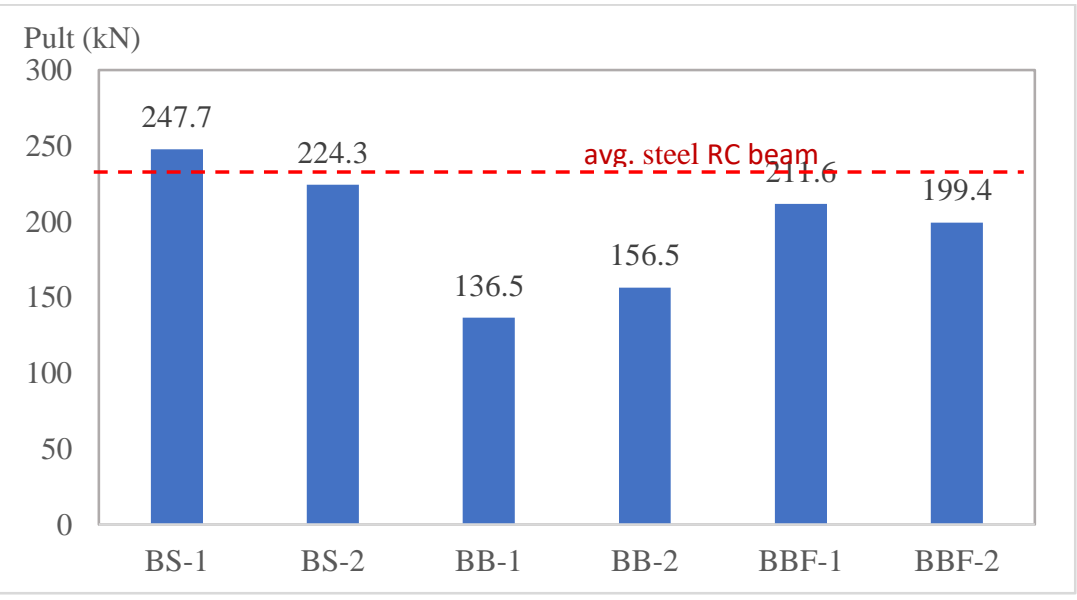

Fig. 11. Failure loads for all tested beams

\subsection{Discussion of Experimental Results}

The failure loads of all tested beams are plotted in Fig. 11. By examining the load displacement relations in Fig. 8, it is observed that concrete beams reinforced with BFRP bars experienced higher deflection values than beams with steel bars, possibly due to the lower stiffness of FRP bars. The mid-span deflection for the same load level for specimen's BB and BBF increased by values ranging from $45 \%$ to $115 \%$ compared to reference specimen BS. Similar findings were reported by El-Nemr et al. [18] for beams reinforced with GFRP bars and by Urbanski et al. [8] for beams reinforced with BFRP. Ge et al. [13] reported that, with the same load, the deflection and the crack spacing of BFRP RC beams are higher than steel RC beams. 
Pawlowski and Szumigala [10] reported that deflections of steel RC beams were $60-70 \%$ less than those of BFRP beams with the same reinforcement ratio. Sunny and Prabhakaran [9] reported that deflection caused by flexural load is more in basalt reinforced beam than steel reinforced beam and attributed this to the lower modulus of elasticity of basalt bars than steel bars, which explains why FRP reinforced concrete beams are recommended by codes to be designed in terms of serviceability limit states. It is observed that addition of steel fibers to beams reinforced with BFRP bars improved the stiffness and flexural capacity of the beams and led to a more ductile behavior, Fig. 8; the average failure load increased by about $40 \%$. Similarly, Awadallah et al. [19] reported that addition of steel fibers increased the ultimate load capacity and stiffness for beams reinforced with BFRP bars and reduced the mid-span deflection by $30 \%$ at the same load. High et al. [12] used chopped basalt fibers to enhance the mechanical properties of concrete and reported increase of the modulus of rupture. Wang and Belarbi [20] reported that fiber reinforced concrete beams reinforced with FRP had better flexural behavior and the ductility level increased more than $30 \%$ compared with FRP reinforced normal concrete beams. Also, Shariq et al. [21] reported that addition of fibers in RC beams delayed the initiation of flexural and shear cracks and yielded ductile failure.

\section{Theoretical Evaluation using Design Guidelines Equations}

\subsection{For Steel Reinforced Section:}

Section properties: $b=200 \mathrm{~mm}, \mathrm{~h}=300 \mathrm{~mm}, \mathrm{~d}=270$ $\mathrm{mm}, \mathrm{A}_{\mathrm{s}}(3 \Phi 16 \mathrm{~mm})=603 \mathrm{~mm}^{2}$, Reinforcement Ratio $\mu=0.0111<\mu_{\max }(0.015)$. Steel reinforcement: $f_{\mathrm{y}}=$ $600 \mathrm{MPa}, E_{\mathrm{s}}=200,000 \mathrm{MPa}$.

a) Calculation of Moment Capacity according to ACI 318-18 [22]:

Concrete: $f_{c}^{\prime}=30.8 \mathrm{MPa}, E_{c}=26500 \mathrm{MPa}$,

As $* f_{y}=0.85 * f^{\prime}{ }_{c} * \beta_{1} * \mathrm{c} * \mathrm{~b}$

where $\beta_{1}=0.831$ for $f^{\prime}{ }_{c}>28 \mathrm{MPa}$;
Therefore, $\mathrm{a}=69.55 \mathrm{~mm}, \mathrm{c}=83.65 \mathrm{~mm}$

Nominal Moment Capacity

$\mathrm{M}_{\mathrm{n}}=\mathrm{As} * f_{y} *\left(\mathrm{~d}-\left(\beta_{1} * \mathrm{c}\right) / 2\right.$

Nominal Moment Capacity $\underline{M}_{n}=85104.37$ N.m,

Nominal Load $\underline{\mathrm{P}_{\mathrm{n}}}=226.94 \mathrm{kN}$

b) Calculation of Moment Capacity according to ECP 203-18 [23]:

Concrete: $f_{c u}=38.25 \mathrm{MPa}, E_{c}=27212.49 \mathrm{MPa}$

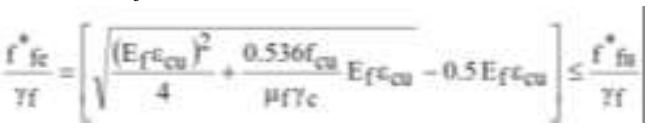

$\mathrm{As} * f_{y}=0.67 * f_{c u} * \mathrm{a} * \mathrm{~b}$

$\mathrm{a}=A_{\mathrm{s} .} f_{\mathrm{y}} /\left(0.67 * f_{\mathrm{cu}} * \mathrm{~b}\right)=70.58 \mathrm{~mm}$

$\mathrm{y}_{\mathrm{ct}}=\mathrm{d}-\mathrm{a} / 2=234.70 \mathrm{~mm}, \mathrm{y}_{\mathrm{ct}} / \mathrm{d}=0.869<0.95$

$M_{\mathrm{u}}=A_{\mathrm{s}} * f_{\mathrm{y}} *(\mathrm{~d}-\mathrm{a} / 2)$

Ultimate Moment Capacity $\underline{\mathrm{M}_{\mathrm{u}}=84916.59 \text { N.m, }}$

Ultimate Load $\quad \underline{\mathrm{P}_{u}=226.44 \mathrm{kN}}$

\subsection{For BFRP Reinforced Section}

Section: $b=200 \mathrm{~mm}, \mathrm{~h}=300 \mathrm{~mm}, \mathrm{~d}=270 \mathrm{~mm}, A_{\mathrm{f}}$ $(2 \Phi 15 \mathrm{~mm})=353.429 \mathrm{~mm}^{2}$

$$
\mathrm{M}_{\mathrm{u}}-\left(\frac{\mathrm{A}_{\mathrm{f}} \mathrm{r}^{\mathrm{N}} \mathrm{re}}{\gamma_{\mathrm{r}}}\right)\left(\mathrm{d} \frac{\mathrm{a}}{2}\right)
$$

Concrete: $f_{c u}=38.25 \mathrm{MPa}, f^{\prime}{ }_{c}=30 \mathrm{MPa}$ maximum concrete strain $\varepsilon_{c u}=0.003$

BFRP bars: Ultimate BFRP tensile strength $f_{f u} *=900$ $\mathrm{MPa}$, tensile modulus $E_{\mathrm{f}}=57000 \mathrm{MPa}$, ult. tensile strain $\varepsilon \mathrm{fu}^{*}=0.015$, Area of bars $\left(\mathrm{mm}^{2}\right)=2 \mathrm{~T} 15 \mathrm{~mm}=$ $353.429 \mathrm{~mm}^{2}$, Reinforcement Ratio $\mu_{\mathrm{f}}=A_{\mathrm{f}} / b . d=$ $353.43 /(200 * 270)=0.00654$.

The failure mode is governed by concrete crushing when the reinforcement ratio $\mu_{\mathrm{f}}$ is greater than the balanced reinforcement ratio $\mu \mathrm{fb}$

a) Calculation of Moment Capacity according to ACI 440.1R-15 [16]:

The balanced reinforcement ratio $\rho_{\mathrm{fb}}$ is described by

$$
\rho_{f b}=0.85 \beta_{1} \frac{f_{c}}{f_{f u}} \frac{E_{f} \varepsilon_{c u}}{E_{f} \varepsilon_{c u}+f_{f u}}
$$

In Eq. (3), $\beta_{1}$ is the ratio of depth of equivalent rectangular stress block to depth of the neutral axis. Taken $\beta_{1}=0.831$, balanced RFT. Ratio $\rho_{\mathrm{fb}}=0.0039>$ minimum RFT. ratio $\left(\rho_{\min }=0.0022\right)$

Reinforcement Ratio $\rho_{\mathrm{f}}=A_{\mathrm{f}} / b . d=353.43 /(200 * 270)$ $=0.00654>\rho_{\mathrm{fb}}$

$\rho_{\mathrm{f}} / \rho_{\mathrm{fb}}=1.67>1.4$

$f_{f}=\sqrt{\frac{\left(E_{f} \varepsilon_{c u}\right)^{2}}{4}+\frac{0.85 \beta_{1} f^{\prime} c}{\rho_{f}} E_{f} \varepsilon_{c u}}-0.5 E_{f} \varepsilon_{c u} \leq f_{f u}$

Stress in BFRP bar $f_{f}=679.31 \mathrm{MPa}$

Depth of concrete stress block $a$ 
$a=\frac{A_{f} f_{f}}{0.85 f^{\prime}{ }_{c} b}$

$a=46.15 \mathrm{~mm}$

$M_{n}=\rho_{f} f_{f}\left(1-0.59 \frac{\rho_{f} f_{f}}{f^{\prime}{ }_{c}}\right)$ for $\rho_{f}>\rho_{f b}$

Nominal Moment Capacity $\mathrm{M}_{\mathrm{n}}=59266.82$ N.m,

Nominal Load $\quad \underline{\mathrm{P}_{\mathrm{n}}=158.04 \mathrm{kN}}$

a) Calculation of Moment Capacity according to ECP 208-05 [24]:

Balanced RFT. Ratio $\mu_{\mathrm{fb}}=0.003$, minimum RFT.

Ratio $\mu_{\min }=0.0022$

$\mu_{\mathrm{f}} / \mu_{\mathrm{fb}}=1.72>1.4$

Stress in BFRP bar $f^{*} f e / \gamma_{\mathrm{f}}=482.3 \mathrm{MPa}$, check that $f^{*} f e / \gamma_{f} \leq f^{*} f u / \gamma_{f}$

Depth of concrete stress block $a=56.5 \mathrm{~mm}$

Ultimate moment $\mathrm{Mult}=41205.51 .7$ N.m.

Ultimate Load $\quad \underline{P_{u l t}}=109.88 \mathrm{kN}$

\subsection{For BFRP Reinforced Section with dispersed} Steel Fibers

Section: $b=200 \mathrm{~mm}, \mathrm{~h}=300 \mathrm{~mm}, \mathrm{~d}=270 \mathrm{~mm}, A_{\mathrm{f}}$ $(2 \Phi 15 \mathrm{~mm})=353.429 \mathrm{~mm}^{2}$

Concrete: $f_{c u}=43.80 \mathrm{MPa}, f^{\prime}{ }_{c}=35.0 \mathrm{MPa}$ maximum concrete strain $\varepsilon_{c u}=0.003$

BFRP bars: Ultimate BFRP tensile strength $f_{f u} *=900$ $\mathrm{MPa}$, tensile modulus $E_{\mathrm{f}}=57000 \mathrm{MPa}$, ult. tensile strain $\varepsilon_{\mathrm{fu}}{ }^{*}=0.015$, Area of bars $\left(\mathrm{mm}^{2}\right)=2 \mathrm{~T} 15 \mathrm{~mm}=$ $353.429 \mathrm{~mm}^{2}$, Reinforcement ratio $\rho_{\mathrm{f}}=A_{\mathrm{f}} / b * d=$ $353.43 /(200 * 270)=0.00654$.

\section{a) Calculation of moment capacity according to ACI} 440.1R-15 [16]:

$\beta_{1}=0.85$ for for $\mathrm{F} \dot{\mathrm{c}}<28 \mathrm{MPa}$

The balanced rft ratio $\rho_{\mathrm{fb}}=0.00423$, minimum RFT. ratio $\rho_{\min }=0.0026$

Reinforcement ratio $\rho_{\mathrm{f}}=A_{\mathrm{f}} / b . d=353.43 /(200 * 270)$

$=0.00654>\rho_{\mathrm{fb}}$

$\rho_{\mathrm{f}} / \rho_{\mathrm{fb}}=1.55>1.4$

Stress in BFRP bar $f_{f}=708 \mathrm{MP}$, depth of concrete stress block $a=42 \mathrm{~mm}$

Ultimate moment $\mathrm{M}_{\mathrm{n}}=62288.86 \mathrm{~N} \cdot \mathrm{m}, \mathrm{P}_{\mathrm{n}}=166.1 \mathrm{kN}$

b) Calculation of Moment Capacity according to ECP 208-04 [24]:

Balanced rft. ratio $\mu_{\mathrm{fb}}=0.00435$, minimum rft. ratio $\mu_{\min }=0.0022$

$\mu_{\mathrm{f}} / \mu_{\mathrm{fb}}=1.505>1.40$

Stress in FRP bar $f * f e / \gamma_{\mathrm{f}}=521.2 \mathrm{MPa}<529.4$

Depth of concrete stress block $a=53.35 \mathrm{~mm}$

Ultimate moment $\underline{\mathrm{M}_{u l t}=44823.9 \mathrm{~N} . \mathrm{m}, \mathrm{Pult}_{\mathrm{u}}=119.5 \mathrm{kN}}$

From the results given in Table 4, it can be observed that for beams reinforced by steel bars, the code calculated ultimate moment is lower than the values obtained experimentally by about 4\% for both ACI318-18 and ECP203-18. For beams reinforced by BFRP bars, the calculated ultimate moment by ECP208-05 is lower than the experimental values by about 33 $\%$ and overestimated by $6 \%$ for ACI 440-R15 design guidelines. For steel fibrous concrete beams reinforced with basalt bars, codes results were underestimated by $24 \%$ and $72 \%$ for ACI440-R15 and ECP208-05, respectively. This can be attributed to the special behavior of concrete with steel fibers regarding crack development preceding failure.

\begin{tabular}{|c|c|c|c|c|c|c|c|}
\hline $\begin{array}{c}\text { Beam } \\
\text { ID }\end{array}$ & $\begin{array}{l}f^{\prime} f_{\text {cu }} \\
(\mathrm{MPa})\end{array}$ & Bottom rft. & Code/ Guidelines & $\mathrm{M}_{\mathrm{u} . \text { Theor. }}(\mathrm{Nm})$ & $\begin{array}{c}\text { Pu.Theor. } \\
(\mathrm{kN})\end{array}$ & $\begin{array}{l}\text { Avg. Pexp. } \\
(\mathrm{kN})\end{array}$ & $\begin{array}{c}\mathrm{P}_{\exp } / \\
\mathrm{P}_{\text {u.Theor. }}\end{array}$ \\
\hline \multirow{2}{*}{ BS } & \multirow{2}{*}{$\begin{array}{l}30.60 / \\
38.25\end{array}$} & \multirow{2}{*}{ Steel $3 \varnothing 16$} & ACI 318-18 & 85104.4 & 226.94 & \multirow{2}{*}{236.20} & 1.04 \\
\hline & & & ECP 203-18 & 84916.6 & 226.44 & & 1.04 \\
\hline \multirow{2}{*}{ BB } & \multirow{2}{*}{$\begin{array}{l}30.60 / \\
38.25\end{array}$} & \multirow{2}{*}{ BFRP $2 \varnothing 15$} & ACI 440-R15 & 58610.8 & 156.29 & \multirow{2}{*}{146.50} & 0.94 \\
\hline & & & ЕCP 208-05 & 41205.5 & 109.88 & & 1.33 \\
\hline \multirow{2}{*}{$\mathrm{BBF}$} & \multirow{2}{*}{$\begin{array}{l}35.04 / \\
43.80 \\
\end{array}$} & \multirow{2}{*}{ BFRP $2 \varnothing 15$} & ACI 440-R15 & 62288.9 & 166.1 & \multirow{2}{*}{205.50} & 1.24 \\
\hline & & & ECP 208-05 & 44823.9 & 119.5 & & 1.72 \\
\hline
\end{tabular}

Table 4. Comparison between experimental and theoretical results

\section{Conclusions}

This paper presents an experimental study of the flexural behavior of concrete beams reinforced by BFRP. The experimental procedures were described and the results were compared with equations provided by design guidelines.
Further, numerical modeling and nonlinear analysis were carried out for the tested beams to compare numerical and experimental results. Based on these studies, the following main conclusions may be drawn: 
1. Concrete beams reinforced by BFRP bars with reinforcement ratio $\rho_{f}$ greater than the balanced reinforcement ratio $\rho_{f b}$, as recommended by design codes showed linear load-displacement relation up to the moment of failure, which occurred at relatively large deflections. The failure mode was governed by concrete crushing.

2. Deflections in BFRP RC beams exceed those of steel RC beams by percentages ranging from $40 \%$ to $125 \%$.

3. It is thus recommended that design of BFRP RC beams should be governed by the Serviceability Limit States.

4. Addition of steel fibers significantly increased the flexural behavior of BFRP RC beams. It caused about $40 \%$ increase in the maximum load and $30 \%$ decrease in midspan deflection at the same load level.

5. The test results highlight the necessity for designing BFRP-reinforced flexural members to fail in compression; design is to be controlled by serviceability requirements due to the low modulus of elasticity of the bars.

6. Theoretical prediction of ultimate load of beams reinforced by BFRP bars using ACI 440.1R-15 and ECP 208-04, compare well to the experimental results for normal concrete. However, for BFRP reinforced beams with dispersed steel fibers, code predictions underestimated the flexural capacity.

\section{References}

[1] Bank L.C., Composites for Construction: Structural Design with FRP Materials, John Wiley \& Sons, Hoboken, NJ, 2006, $560 \mathrm{p}$.

[2] Sim, J., Park, C, Moon, D., "Characteristics of basalt fiber as a strengthening material for concrete structures", Composites Part B: Engineering, 2005; 36 (6-7), 504-512.
[3] Wei, B., Cao, H., Song, S., "Environmental resistance and mechanical performance of basalt and glass fibers", Material Science and Engineering A, 2010, 527, 4708-4715.

[4] Wu, Z., Wang, X., Wu, G., "Advancement of structural safety and sustainability with basalt fiber reinforced polymers", In: Proc. $6^{\text {th }}$ Int. Conf. on FRP Composites in Civil Engineering CICE, Rome, Italy, 2012, p. 29.

[5] Monaldo, E., Nerilli, F., Vairo, G., "Basaltbased fiber-reinforced materials and structural applications in civil engineering”, Composite Structures, 2019, 214, 246-263.

[6] Elgabbas, F., Ahmed, E., Benmokrane, B., "Physical and mechanical characteristics of new basalt-FRP rods for reinforcing concrete structures", Construction and Building Materials, 2015; 95:623-635.

[7] Serbescu, A., Guadagnini, M., Pilakoutas, K., "Mechanical characterization of basalt FRP rebars and long-term strength predictive model", J. Composites in Construction, 2014, 19(2):04014037.

[8] Urbanski, M., Lapko, A., Garbacz, A., "Investigation on concrete beams reinforced with basalt rebars as an effective alternative of conventional R/C structures", $11^{\text {th }}$ International Conference on Modern Building Materials, Structures and Techniques, NBMST 2013, Procedia Eng., 2013; 52:1183-1191.

[9] Sunny, J.C., Prabhakaran, P., "Experimental study on properties of concrete reinforced with basalt bars", International Research Journal of Engineering and Technology (IRJET), Vol. 3 (7), July 2016, 1524-1529.

[10] Pawlowski D., Szumigala M., "Flexural behavior of full-scale basalt FRP RC beams - experimental and numerical studies", $\quad 7^{\text {th }} \quad$ Scientific-Technical Conference Material Problems in Civil 
Engineering (MATBUD 2015), Procedia Engineering, 108, 2015, 518-525.

[11] Elgabbas, F., Vincent, P., Ahmed, E. A., Benmokrane B., "Experimental testing of basalt-fiber-reinforced polymer bars in concrete beams", Composites Part B: Engineering, 91 (2016) 205-218.

[12] High, C., Seliem, H.M., El-Safty, A., Rizkalla, S.H., "Use of basalt fibers for concrete structures", Construction and Building Materials, 2015; 96: 37-46.

[13] Ge, W., Zhang, J., Cao, D., Tu, Y., "Flexural behaviors of hybrid concrete beams reinforced with BFRP bars and steel bars", Construction and Building Materials, 2015; 87:28-37.

[14] Ma, G., Huang, Y., Aslani, F., Kim, T., "Tensile and bonding behaviors of hybridized BFRP-steel bars as concrete reinforcement", Construction and Building Materials 201, 2019, 62-71.

[15] ASTM C150 / C150M-20, Standard Specification for Portland Cement, ASTM International, West Conshohocken, PA, 2020, www.astm.org.

[16] ACI 440.1R-15., "Guide for the Design and Construction of Structural Concrete Reinforced with Fiber-Reinforced Polymer (FRP) Bars," ACI Committee 440, American Concrete Institute, Farmington Hills, MI, 2015, pp.16.

[17] ASTM D7205/D7205M-06 (Reapproved 2011), "Standard Test Method for Tensile Properties of Fiber Reinforced Polymer Matrix Composite Bars," Annual Book of ASTM Standards, ASTM International, West Conshohocken, PA, USA, 2011, pp. 13.

[18] El-Nemr, A., Ahmed, E., Benmokrane, B., "Instantaneous deflection of slender concrete beams reinforced with GFRP bars. In: Proc., 2nd int. engineering mechanics and materials specialty conference, Ottawa, Ontario. Canada: CSCE; 2011. p. 10.

[19] Awadallah Z., Ahmed M., Farghal O., and Fahmy M., "Some parameters affecting shear behavior of high strength fiber reinforced concrete beams longitudinally reinforced with BFRP rebars," Journal of Engineering Sciences, Assiut University, 42, 5, 2014, 1163-1178.

[20] Wang, H., Belarbi, A., "Ductility characteristics of fiber-reinforced-concrete beams reinforced with FRP rebars", Constr. Build. Mater. 25 (5) (2011) 23912401.

[21] Shariq, M., Khan, A. A., Masood, A., Arif, M., Baqi, A., "Experimental and analytical study of flexural response of RC Beams with steel fibers after elevated temperature", Iranian Journal of Science and Technology, Transactions of Civil Engineering, April 2020, DOI: 10.1007/s40996-020-00408-7

[22] ACI 318-18, "Building Code Requirements for Structural Concrete and Commentary," ACI Committee 318, American Concrete Institute, Farmington Hills, MI, 2018, pp. 129.

[23] ECP 203-2018, "Egyptian Code of Practice for Design and Construction of Reinforced Concrete Structures", Housing and Building National Research Center, Ministry of Housing and Urban Communities, Egypt, 2018.

[24] ECP 208-2005, "Egyptian Code of Practice for the use of Fiber Reinforced Polymers in the Construction Fields", Housing and Building National Research Center, Ministry of Housing and Urban Communities, Egypt, 2005. 


\section{دراسة معملية لسلوك الكمرات الخرسانية المسلحة بقضبان من البوليمرات المسلحة بألياف البازلت}

تعتبر القضبان من البوليمر ات المسلحة بألياف البازلت من المو اد المستحدثة و المستخدمة كبديل لقضبان الصلب في تسليح

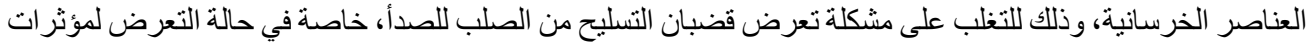

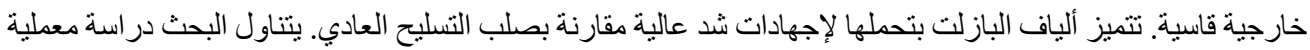
وتحليلية للكمرات الخرسانبة المسلحة داخليا بقضبان من البوليمرات المسلحة بألياف البازلت عوضا عن التسليح المعتاد

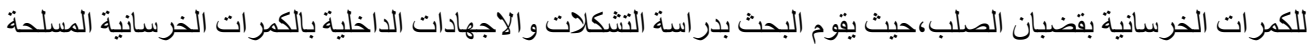

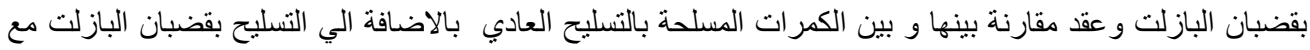
خرسانة مضاف اليها ألياف الصلب. وقد تمت الدراسة علي عدد من الكمرات بسيطة الارتكاز و عمل دراسة تحليلية لتقييم

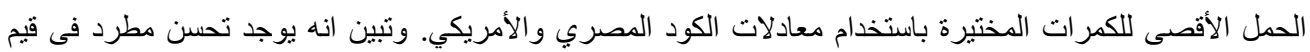
التشكلات و الاجهادات باستبدال قضبان البازلت بدلا من الصلب العادى على سلوك الكمرة في الانحناء. 